080

Received: June 5, 2009

Accepted: November 20, 2009
Macedonian Journal of Animal Science, Vol. 2, No. 1, pp. 67-69 (2012)

In print ISSN $1857-6907$

On line ISSN $1857-7709$

UDC: $637.5: 598.721 .1$

Original scientific paper

\title{
CARCASS CATEGORIZATION AND CHEMICAL COMPOSITION OF OSTRICH MEAT
}

\author{
Aco Kuzelov, Momčula Jordanoski, Živko Gacovski, Dijana Trajčova \\ University "Goce Delčev", Faculty of Agriculture, \\ Blvd. Krste Misirkov, bb. Štip, Republic of Macedonia \\ aco.kuzelov@ugd.edu.mk
}

\begin{abstract}
This paper presents yield and carcass categorization of ostriches. The categories are the first, second, third, fourth and fifth and parts of rump, back and drumstick with muscles of these parts. In this paper the results of chemical composition of ostrich meat are also presented. Ostrich slaughter age was 14 months. The primary processing of ostriches examinations were made according to all sanitary - veterinary requests. After the primary processing examinations of chemical composition of ostrich meat (water, fat, proteins and ash) were made. According to the examinations it was realized that ostrich meat contains $76.22 \%$ water, $<0.5 \%$ fats, $1.17 \%$ ash, $22, .41 \%$ proteins.
\end{abstract}

Key words: categorization; meat; ostrich

\section{КАТЕГОРИЗАЦИЈА НА КЛАНИЧНИОТ ТРУП И ХЕМИСКИ СОСТАВ НА МЕСОТО ОД НОЈ}

Во трудот е дадена категоризацијата на кланичен труп на ној (Struthio camelus). Категориите се прва, втора, трета, четврта и петта и деловите се бутот, грбот и карабатакот со мускулите кои ги опфаќаат тие делови. Испитуван е и хемискиот состав на месото од ној. Возраста на ноевите изнесуваше 14 месеци. Примарната обработка на ноевите се изврши запазувајќи ги сите санитарно-ветеринарни барања. По примарната обработка се изврши испитување на хемискиот состав на месото (содржина на вода, масти минерални материи, белковини). Утврдено е дека месото од ној содржи 76,22\% вода, помалку од 0,5\% масти, $1,17 \%$ минерални материи и $22,41 \%$ протеини.

Клучни зборови: категоризација; месо; ној

\section{INTRODUCTION}

In the 1860's the first commercial ostrich farm was established in South Africa for the harvesting of feathers (Joy, 2005). Ostriches are farmed only in South Africa and Israel, until 1986. Commercial ostrich farming became widespread in the end of XX century. Ostriches are farmed in over 50 countries (Australia, Argentina, France, Brazil, Israel, Spain, England, USA, etc.). Most producers grow ostrich for their meat on the first place and feathers, fat, eggs and other parts of the birds as by-products (http://www4.agr.gc.ca /AAFC-AAC/).

A very big attention is dedicated to the rules of slaughtering and primary process for ostriches, especially in Germany, Italy and other West European countries. Ostrich's carcass is categorized in a few categories. The categorization is made according to the bird age, fat pan color, muscle color, heart condition, liver condition, disease condition. The categorization is described in the bulletin of the World Ostrich Association (WOA) carcass grading system, January 2003.

There is a huge interest for ostrich meat all over the world. Ostrich meat is considered alternative of beef meat in dietetic and healthy food point, because of the low fat content and huge protein content. Ostrich meat is very useful for all functions in organism. This meat is rich with iron and minerals. According to modern principals of nu- 
tritition, this meat is the best, compared with other meat (http://www.ostrich.ca).

In the last couple of years, ostrich rearing in Macedonia is spread away, but organization is not good enough. Ostrich carcass categorization and chemical composition are given in this paper.

\section{MATERIALS AND METHODS}

Currently there is no universally accepted method of ostrich carcass classification, but Blue Mountain Feeds, Inc. as a part of WOA has proposed a possible grading system. Now five categories have been used according to the bird age, fat pan color, muscle color, heart condition, liver condition, disease condition (Cooper, 2000).

Ten healthy birds were used for the examination of carcass and chemical composition. Ostriches were 12-14 months old and weight about 100 kilos. Ostriches are reared on farms in Macedonia and slaughtered in "Ži-Va" - the unique slaughter house in Macedonia that can process ostriches. The primary processing of ostriches was made according to all sanitary-veterinary requests. Ostrich carcass was culled in a cooling chamber on 0 to $+4{ }^{\circ} \mathrm{C}$. After the cooling, $500 \mathrm{~g}$ meat was taken from $m$. gastrocnemius. The chemical analyses (water, proteins, ash and fats) were made in the laboratory of MIK Sveti Nikole. The water content was determinate by drying on $105{ }^{\circ} \mathrm{C}$ (AOAC). The fat content was determinate according to the Gerber method. Proteins were determinate by the Kjeldahl method. The mineral materials content was determinate by the ash content determination with mineralization on $550-650{ }^{\circ} \mathrm{C}$.

\section{RESULTS AND DISCUSSION}

For ostrich slaughtering different methods are used in each country. Usually they are slaughtered between $9-14$ months of age. By 14 months of age, an ostrich can yield $35 \mathrm{~kg}$ of meat. Its slaughter weight at this age is approximately $100 \mathrm{~kg}$. Each carcass has $10-20 \mathrm{~kg}$ of high quality meat primarily from the legs (in ratio $66 \%$ steak, $33 \%$ filet) (Cooper, 2000).

The most used ostrich meat carcass grading system in West-Europe and the system that was used by us is:

\section{First category (Prime grade)}

A prime grade carcass is less than 16 months of age. It has white fat pan only and red muscle color throughout. It has heart with normal size, color and texture with no damage and the liver is with mid-brown color with no abscess. There are no disease symptoms or evidence and no edema or "jell" substance of heart, thigh or sternum. A prime grade carcass will yield the highest amount of primary meat cuts with a consistent degree of tenderness throughout all the primary meat muscles.

\section{Second category (Choice grade)}

A choice grade ostrich carcass is $16-24$ months of age. It has white fat pan only and red muscle color throughout. It has heart with normal size, color and texture with no damage and the liver is with mid-brown color with no abscess. There are no disease symptoms or evidence and no edema or "jell" substance of heart, thigh or sternum. A choice grade carcass will yield a few primary meat cuts, if carefully selected, with a reasonable degree of tenderness. The majority of this meat will be secondary meat cuts and ground meat.

\section{Third category (Select grade)}

A select grade ostrich carcass is 25 months of age and older. It has white fat pan only and red muscle color throughout. It has heart with normal size, color and texture with no damage and the liver is with mid-brown color with no abscess. There are no disease symptoms or evidence and no edema or "jell" substance of heart, thigh or sternum. A select grade carcass should only be used for value added products and ground meat products.

\section{Fourth category (Utility grade)}

In this category there are birds of any age. They have yellow fat pan color and multi-coloring of muscles (pink to dark red) with white color areas in some muscles. They have small, damaged or spongy texture heart and the liver has yellow, green or black color with liver abscesses or ulcerations. There are no disease symptoms or evidence, but there are edema or "jell" substance of heart, thigh or sternum. A utility grade carcass should only be used for value added products and not for 
primary cuts, secondary cuts, or ground meat products.

\section{Fifth category (Non-food grade)}

In this category there are birds of any age. They have muscles with abscesses or channels in meat, with light or dark spots. They have spotty or infected livers and there are any disease symptoms or evidence. A non-food grade ostrich carcass will exhibit one or more of the above undesirable traits.

The results of chemical compose examinations of ostrich meat are in Table 1. Meat was taken from six ostriches slaughtered in $\breve{Z} i-\mathrm{Va}-$ Stip, and the chemical analyses were made in the laboratory of MIK Sveti NIkole.

Table 1

\section{Chemical composition of ostrich meat (\%)}

\begin{tabular}{ccccc}
\hline \hline Results & Water & Proteins & Fats & Ash \\
\hline Ostrich 1 & 76.57 & 22.48 & $<0.5$ & 1.13 \\
Ostrich 2 & 75.77 & 22.28 & $<0.5$ & 1.12 \\
Ostrich 3 & 75.85 & 22.67 & $<0.5$ & 1.20 \\
Ostrich 4 & 76.75 & 22.12 & $<0.5$ & 1.11 \\
Ostrich 5 & 76.19 & 22.51 & $<0.5$ & 1.22 \\
Ostrich 6 & 76.23 & 22.43 & $<0.5$ & 1.26 \\
\hline \hline
\end{tabular}

These results are obtained by calculating the average ostrich meat content $76.22 \%$ water, $<0.5$ $\%$ fats, $1.17 \%$ ash, $22.41 \%$ proteins.

Ostrich meat is the leanest red meat. Other meat types contain not less than $3 \%$ fats and in ostriches there is no muscle that contains more than $0.3 \%$ fats. The average fat content in filets muscles is about $0.032 \%$ and in steak muscles is about $0.155 \%$. Ostrich meat is also rich with proteins about $26 \%$ (Krajbih and Zomer, 1994).

Ostrich meat is a great source of selenium, iron, phosphor, zinc, copper. Cholesterol content is very small and that's why this meat is great dietetic product (Dragoev, 2004). Ostrich meat is rich with B vitamins, especially B6 and B12. They protect cardiovascular system and they transmit homocystein into safety form. The last examinations show that homocystein is a risk factor not only for cardiovascular disease but for osteoporosis too (Sales, 1998; Hoffmann and Fisher, 2001).

\section{CONCLUSION}

Ostrich production is highly management intensive. Ostrich meat has found place in the world's menu and continues to find its way into our local restaurants. Ostrich meat yield is about $35 \mathrm{~kg}$ meat from a bird at the slaughter age of $12-$ 14 months and slaughter weight about $100 \mathrm{~kg}$. Ostrich red meat is similar to the beef by taste, but soft and with short myofibrils like chicken meat.

Fat content $(<0.5 \%)$ in ostrich meat is very small, so it can be used like a dietetic product. Fat in ostriches is collected outside the muscles and is easy to remove during processing. It is ideal for weight watchers who love red meat. Ostrich meat is rich with proteins $(22.415 \%)$ that increase its nutritive value. Ostrich meat can be used in any traditional recipe to produce great tasting dishes. Most of the meat from an ostrich comes from the leg, thigh and back.

\section{REFERENCES}

[1] AOAC, Official methods of Analysis of the Assoc. of Anal. Chemists, 11 Edn., Ed. H. William, Washington D.C., 20044, 1970.

[2] Cooper R. G. (2000): Meat from the ostrich - Slaughtering, meat inspection and health risks, Fleish Wirtschaft International.

[3] Драгоев, С. Г. (2004): Развитие на технологията в месната и рибната промишленост. Академично издателство на УХТ - Пловдив, 249-256.

[4] Joy Antoinette (2005): Ostrich farming then and now, World Poultry, Vol. 21, No 3,

[5] Hoffman, L. C., P. Fisher (2001): Comparison of meat quality characteristics between young and old ostriches. Meat Science, 59 (3), 335-337.

[6] Kjeldahl, J. C. C. T., En my Methode til Kvalstorfbestemmelse, I: Organiske Stoffer. Medd. Carsberg, 2, 112, Anal. Chem., 1883, 22, 336-382.

[7] Krajbih A., Zomer, M. (1994): Uzgoj nojeva, Poljoprivredna izdavačka kuća, Munster - Hiltry.

[8] Sales, J. (1998): Fatty acid composition and cholesterol content of different ostrich muscles.

[9] www.woa.com

[10] http://www4.agr.gc.ca/AAFC-AAC/

[11] http://www.ostrich.ca 
